Hydrology and Earth System Sciences, 8(3), 550-559 (2004) (C) EGU

\title{
The response of macroinvertebrates to artificially enhanced detritus levels in plantation streams
}

\author{
James L. Pretty* and Michael Dobson \\ Department of Environmental and Geographical Sciences, Manchester Metropolitan University, John Dalton Building, Chester Street, Manchester M1 5GD, UK \\ *Present address: School of Biological Sciences, Queen Mary University of London, Mile End Road, London, E1 4NS, UK
}

Email for corresponding author: j.1.pretty@qmul.ac.uk

\begin{abstract}
The leaves and wood from vegetation surrounding headwater streams constitute a major food source for aquatic invertebrates, providing they are retained upon the streambed and not transported downstream. This study investigated the response of aquatic invertebrates to artificially increased detritus retention, in an effort to reproduce the naturally occurring build up of dead organic matter associated with streams in oldgrowth forest. The background detrital standing stock in streams in Kielder Forest (Northumberland, UK) was low, approximately $32 \mathrm{gm}^{-2}$. Two streams flowing through dense conifer plantation and one in open broadleaved woodland were manipulated by the addition of logs over a $10 \mathrm{~m}$ stream reach. After several months, log addition significantly enhanced detrital standing stocks in both conifer and broadleaved streams. Total invertebrate abundance, taxon richness and the numbers of certain numerically dominant families were significantly higher in experimental than reference reaches in both conifer and broadleaved streams. This response was most marked for detritivores, whilst nondetritivore groups often showed no response to the manipulation. Whilst in the short term the responses to enhanced retention may reflect a redistribution of the local fauna, it is argued that over a longer time-scale, a genuine increase in invertebrate density and diversity could occur. Allowing old-growth forest to develop in planted valley bottoms may be a viable management option for conservation. If established alongside streams, it would ensure continuous input of woody material and the fauna may benefit from the resulting increase in detritus retention.
\end{abstract}

Keywords: forestry, detritivores, old-growth conifers, river management, woody debris

\section{Introduction}

Commercial harvesting for timber and pulpwood is a major environmental impact in forested regions of the world. In addition to perturbations caused by logging activities, much commercial forestry now depends heavily on planted monocultures, often of exotic tree species. As such, the presence of the forest itself also constitutes a potentially detrimental environmental impact. In the United Kingdom today, over $60 \%$ of woodland comprises plantations of exotic conifers, particularly the North American Sitka spruce (Picea sitchensis (Bong.) Carr.). Most plantations were established during the second half of the 20th Century in upland areas formerly constituting open moorland or rough grazing land, the conversion of which to forest therefore represented a major land use change. Water courses in such areas are susceptible to changes in land management wrought by large-scale plantation of trees. Hydrology, sediment yield, water chemistry and temperature have been altered (Hornung and Newson, 1986; Leeks and Roberts, 1987; Weatherley and Ormerod, 1990; O'Halloran and Giller, 1993; Ormerod et al., 1993), with associated adverse effects on their biota (Ormerod et al., 1987; Tierney et al., 1998).

Forestry also has an energetic impact on upland streams by altering the availability of different food sources for the stream biota. Open streams are poorly retentive of the organic matter that enters the stream from riparian vegetation and have low detrital standing stocks (Cariss and Dobson, 1997). However, they are characterised by high algal production, providing the major energy resource for primary consumers (Behmer and Hawkins, 1986). In naturally wooded streams, where primary production is suppressed 
by shading, the major energy resource is provided by allochthonous leaf litter whose retention is significantly enhanced by pieces of dead wood (DW) such as branches, twigs and occasionally entire trees that fall into the channel (Pozo et al., 1998). In conifer plantations, however, retention is low because trees are harvested before they begin to drop branches to any great extent. Therefore, plantation streams may retain the low retentive capacity of moorland streams but suffer from a reduction in algal production through heavy, permanent shading (Friberg and Kjeldsen, 1994; Friberg, 1997). A further detrimental impact is the generally low quality of conifer needles as a food resource for detritivores (Bärlocher et al., 1978; Graça and Pereira, 1995). If retained on the streambed for a long enough period of time, needle quality is improved by microbial conditioning and they can support large numbers of invertebrates (Grafius and Anderson, 1980). Low retention generally precludes this from occurring and as a consequence, invertebrate abundance is generally lower than in equivalent streams shaded by broadleaved woodland (Friberg et al., 2002).

Management of upland streams in the United Kingdom needs to address the issue of reduced energy supply. Modern forestry practice avoids planting in the riparian zone (Forestry Commission, 1993) but, in many older plantations, the commercial crop overhangs water courses. In some sites, streamside trees have been removed to increase light inputs, but the process of removal is disruptive with minimal benefits (Ormerod et al., 1993). An alternative approach may be to enhance retention capacity of impacted stream channels (Dobson et al., 1995; Haapala and Muotka, 1998). Ideally, this would be in the form of buffer zones removed from commercial activity (Forestry Commission, 1993; Dobson and Cariss, 1999). In practice, however, these take many years to develop, and experimental assessments of their potential effectiveness are required.

This study describes a manipulation of retention in streams running through intensive commercial forestry where inputs were dominated by low quality coniferous material and retention was predicted to be low. The aim of the study was to determine the effect of permanent retention structures on the detrital standing stock and invertebrate communities, and to assess the viability of using detritus retention as a management tool.

\section{Methods}

\section{STUDY AREA}

The Kielder Forest in Northumberland is the largest area of conifer plantation in Britain, covering around $475 \mathrm{~km}^{2}$. The plantation is dominated by two exotic species - the most widely planted tree is Sitka spruce, while Norway spruce (Picea abies (L.) Karsten) dominates valley bottoms - and is managed intensively for commercial forestry. The forest ranges in altitude from 150 to $500 \mathrm{~m}$ and is characterised by gleyed and peaty soils. The area was previously open moorland and rough grazing ground until the onset of afforestation in 1926. The most intensive period of planting occurred between 1946 and 1960, when $200 \mathrm{~km}^{2}$ were planted (Hibberd, 1985).

Three low order streams were used for this study (Table 1). Capon Burn and Kittythirst ran through dense (approximately 40 year old) spruce plantation, with trees planted up to the water's edge and completely overshading the channels. Steep Sike drained a spruce plantation but had a riparian zone of alder (Alnus glutinosa (L.) Gaertn.), under whose open canopy was an understorey of grasses.

\section{STUDY DESIGN}

In each stream, a $20 \mathrm{~m}$ stretch was chosen and divided into the upstream reference and downstream experimental reach (each $10 \mathrm{~m}$ long). All benthic samples were taken using a Surber sampler (area $0.0625 \mathrm{~m}^{2}$, mesh size $250 \mu \mathrm{m}$ ) and the contents preserved on site with $4 \%$ formalin. Immediately before manipulation, five benthic samples were taken at random from each reach to enable a pre-manipulation comparison between reaches.

Capon Burn and Kittythirst were manipulated in April

Table 1. Summary of the sites used in this study. Conductivity and $\mathrm{pH}$ measurements are based on field readings taken on each sample collection date.

\begin{tabular}{lllllllll}
\hline Site & $\begin{array}{l}\text { Grid } \\
\text { Ref. }\end{array}$ & $\begin{array}{l}\text { Altitude } \\
(\mathrm{m})\end{array}$ & $\begin{array}{l}\text { Stream } \\
\text { Order }\end{array}$ & $\begin{array}{l}\text { Mean } \\
\text { width }(\mathrm{m})\end{array}$ & $\begin{array}{l}\text { Slope } \\
(\%)\end{array}$ & $\begin{array}{l}\text { Mean } \mathrm{pH} \\
(\text { range })\end{array}$ & $\begin{array}{l}\text { Conductivity } \\
\left(\mu \mathrm{sm}^{-1}\right)\end{array}$ & Riparian vegetation \\
\hline Capon Burn & NY630914 & 210 & 1 & 1.8 & 3.1 & $6.1(4.2-7.6)$ & 77 & Shaded, semi-mature spruce \\
Kittythirst & NY609962 & 230 & 1 & 1.6 & 3.5 & $7.6(7.2-8.3)$ & 241 & Shaded, semi-mature spruce \\
Steep Sike & NY624890 & 240 & 1 & 1.2 & 5.0 & $5.5(3.9-6.6)$ & 56 & Lightly shaded, alder buffer strip \\
\hline
\end{tabular}


1997; Steep Sike was manipulated in October 1997. The streams were manipulated by adding ten round logs (Sitka spruce) to the experimental reach. Each log was secured perpendicular to the flow (using four steel poles) and spaced approximately one metre apart. The $\log$ s used in the manipulation were approximately $1 \mathrm{~m}$ long and $0.1 \mathrm{~m}$ in diameter, with all side branches removed; they were harvested locally several weeks prior to manipulation and had been stored in the open prior to use. The logs were chosen for the manipulation because they were widely available and their simple structure enabled easy replication.

Following manipulation, benthic samples were taken from experimental streams at approximately three-monthly intervals until April 1999. In each reach, samples were taken from five random points, with the exception that no given point was sampled on consecutive dates. In experimental reaches, the physical structure of the manipulation and of the Surber sampler meant that samples could be taken effectively only immediately downstream of logs.

\section{Sampling and data processing}

In the laboratory, invertebrates were removed from each sample and identified to species and counted; early instar insect larvae, tipulids and chironomids were identified to genus or family. The organic matter caught in the samples was dried at $60^{\circ} \mathrm{C}$ for $48 \mathrm{~h}$ and separated into non-woody and woody fractions. The woody fraction included sticks and twigs $<2 \mathrm{~cm}$ in diameter; larger material was omitted from the study because it was rarely caught and the scale of the study was inappropriate to assess such inputs (Campbell et al., 1992). After drying, non-woody and woody fractions were weighed, burned at $550^{\circ} \mathrm{C}$ for $3 \mathrm{~h}$ and re-weighed to attain ash-free dry mass (AFDM).

\section{DATA ANALYSIS}

The primary comparison of interest was reference versus experimental reaches. Steep Sike was manipulated later than the other sites to replace a site that was unsuitable, and therefore, the experimental design was unbalanced. For this reason, data from each site were analysed separately, a strategy further justified on the grounds that the sites all showed intrinsic differences (see Table 1) which would have confounded the main comparison.

\section{Pre-manipulation}

To ensure that the reference and experimental reaches were comparable prior to manipulation, each stream was compared separately for mass of non-woody and woody detritus. The invertebrate fauna at each site was compared for total abundance and mean taxon richness per sample. In addition, species data were aggregated to compare the abundance of numerically dominant families (families which constituted over $2 \%$ of the total invertebrate assemblage at each site). These categories were analysed separately for each stream using independent samples $t$-tests. Significance levels were adjusted using a Bonferroni correction because multiple comparisons were made. Data were $\log _{10}(n+1)$ transformed where appropriate to satisfy assumptions of normality and homogeneity of variances.

\section{Post-manipulation}

Post-manipulation samples were compared using the same categories as the pre-manipulation analysis. To investigate whether the manipulation had a significant effect on detritus levels or the invertebrate fauna, two-way ANOVA was carried out with date and treatment (reference versus manipulation) as the tested variables. Data were $\log _{10}(n+1)$ transformed where required.

\section{Results}

\section{PRE-MANIPULATION}

The pre-manipulation samples taken in April 1997 for Capon Burn and Kittythirst and October 1997 for Steep Sike are summarised in Table 2. There were no significant differences between reference and experimental samples in the standing stock of detritus or DW at all three sites. In Capon Burn and Steep Sike, there were no differences in invertebrate numbers between reaches. These results indicate that the reference and manipulation reaches were similar enough prior to manipulation to be compared experimentally.

At Kittythirst, some components of the invertebrate community differed between the reference and manipulation reaches (Table 2). Total invertebrate abundance and numbers of baetid mayflies and chironomids were significantly greater in the reference reach. Because of these significant differences between the reaches before manipulation, postmanipulation results for Kittythirst should be interpreted with caution. However, it should be noted that the mass of detritus, taxon richness and abundance of numerous invertebrate families were similar enough between reaches to allow valid comparisons after manipulation.

\section{POST-MANIPULATION}

\section{Detritus}

The standing stock of non-woody detritus in the reference reach was low for all three streams (Fig. 1a). Similarly, DW was rarely found in the reference samples of each stream (Fig. 1b). At Capon Burn and Steep Sike, the manipulation 
Table 2. Premanipulation comparison of reference and manipulation samples for each stream. Mean values are expressed as mass or numbers per $0.0625 \mathrm{~m}^{2}$. Invertebrate families are listed in order of their relative abundance (\%) over the duration of the study. $\mathrm{df}=8$ in all cases. Critical significance levels were adjusted (Bonferroni) to account for multiple testing; Capon Burn $\alpha=0.006$, Kittythirst $\alpha=0.005$, Steep Sike $\alpha=0.006$.

\begin{tabular}{|c|c|c|c|c|}
\hline & $\begin{array}{l}\text { Reference Reach } \\
\text { Mean (SD) }\end{array}$ & $\begin{array}{l}\text { Experimental Reach } \\
\text { Mean (SD) }\end{array}$ & t-value & $P$ \\
\hline \multicolumn{5}{|l|}{ CAPON BURN } \\
\hline Non-woody detritus & $0.49(0.52)$ & $0.44(0.24)$ & 0.01 & 0.99 \\
\hline Woody detritus & $0.0(0.0)$ & $0.0(0.0)$ & - & - \\
\hline Total invertebrates & $51.4(34.35)$ & $47.0(15.36)$ & 0.01 & 0.99 \\
\hline Taxon richness & $11.2(1.3)$ & $10.2(3.19)$ & 0.82 & 0.435 \\
\hline Chironomidae (25.0\%) & $1.8(1.1)$ & $1.8(3.03)$ & 0.74 & 0.480 \\
\hline Nemouridae (22.3\%) & $17.8(9.68)$ & $13.6(10.43)$ & 0.80 & 0.445 \\
\hline Leuctridae (18.8\%) & $7.6(4.72)$ & $7.8(2.11)$ & 0.08 & 0.941 \\
\hline Baetidae (10.78\%) & $3.0(2.83)$ & $2.0(1.50)$ & 0.07 & 0.949 \\
\hline Simuliidae (6.4\%) & $0.8(0.84)$ & $2.4(4.83)$ & 0.26 & 0.799 \\
\hline Taeniopterygidae (6.0\%) & $15.4(17.59)$ & $14.2(11.08)$ & 0.09 & 0.929 \\
\hline Polycentropodidae (2.4\%) & $1.2(0.84)$ & $1.2(1.64)$ & 0.41 & 0.692 \\
\hline \multicolumn{5}{|l|}{ KITTYTHIRST } \\
\hline Non-woody detritus & $0.8(0.46)$ & $0.97(0.58)$ & 0.53 & 0.611 \\
\hline Woody detritus & $0.0(0.0)$ & $0.0(0.0)$ & - & - \\
\hline Total invertebrates & $126.2(30.33)$ & $49.8(14.18)$ & 5.45 & $<0.001$ \\
\hline Taxon richness & $20.4(4.39)$ & $15.8(4.76)$ & 1.58 & 0.153 \\
\hline Baetidae (28.1\%) & $56.4(14.52)$ & $16.6(8.26)$ & 5.29 & $<0.001$ \\
\hline Gammaridae (17.8\%) & $12.2(17.33)$ & $2.6(1.52)$ & 1.36 & 0.212 \\
\hline Heptageniidae (11.2\%) & $10.8(4.15)$ & $6.8(2.78)$ & 1.65 & 0.138 \\
\hline Leuctridae $(7.4 \%)$ & $23.6(4.98)$ & $18.4(7.47)$ & 1.35 & 0.215 \\
\hline Elmidae (6.3\%) & $13.0(6.52)$ & $3.2(3.84)$ & 3.04 & 0.016 \\
\hline Chironomidae $(5.8 \%)$ & $5.0(1.0)$ & $1.0(1.41)$ & 4.05 & 0.004 \\
\hline Nemouridae (3.9\%) & $2.4(1.14)$ & $2.0(2.55)$ & 0.90 & 0.395 \\
\hline Simuliidae (3.7\%) & $0.2(0.45)$ & $4.6(3.44)$ & 3.04 & 0.016 \\
\hline Tipulidae (2.3\%) & $4.6(2.07)$ & $2.4(1.95)$ & 1.56 & 0.156 \\
\hline \multicolumn{5}{|l|}{ SteEP SiKe } \\
\hline Non-woody detritus & $3.67(2.60)$ & $3.16(1.35)$ & 0.04 & 0.973 \\
\hline Woody detritus & $0.52(0.83)$ & $0.06(0.14)$ & 1.20 & 0.265 \\
\hline Total invertebrates & $103(37.11)$ & $113.8(53.72)$ & 0.36 & 0.729 \\
\hline Taxon richness & $13.8(4.71)$ & $15.6(3.05)$ & 0.88 & 0.402 \\
\hline Nemouridae (33.8\%) & $10.6(9.5)$ & $12.2(13.92)$ & 0.43 & 0.681 \\
\hline Leuctridae (23.0\%) & $30.6(18.23)$ & $44.4(26.7)$ & 1.05 & 0.326 \\
\hline Chironomidae (15.1\%) & $6.2(6.3)$ & $4.6(2.51)$ & 0.10 & 0.924 \\
\hline Simuliidae (7.4\%) & $1.8(4.03)$ & $0.2(0.45)$ & 0.67 & 0.522 \\
\hline Taeniopterygidae (5.1\%) & $0.8(1.79)$ & $0.2(0.45)$ & 0.52 & 0.615 \\
\hline Polycentropodidae $(4.0 \%)$ & $4.4(2.97)$ & $7.6(4.16)$ & 1.00 & 0.346 \\
\hline Leptophlebiidae (4.0\%) & $35.0(23.89)$ & $22.8(10.52)$ & 0.79 & 0.452 \\
\hline
\end{tabular}

was generally slow to have an effect on retention (Fig. 1a, b). However, by August 1998 a considerable increase in detritus levels was apparent at both sites. The same general pattern was found at Kittythirst, although the increase in non-woody detritus was more pronounced in the first half of the study period than the other sites (Fig. 1a). The overall effect of the manipulation in increasing retention was highly significant for each stream, although the slow initial increases in the experimental reaches resulted in significant interaction terms in most cases (Table 3). 
a) Non-woody detritus
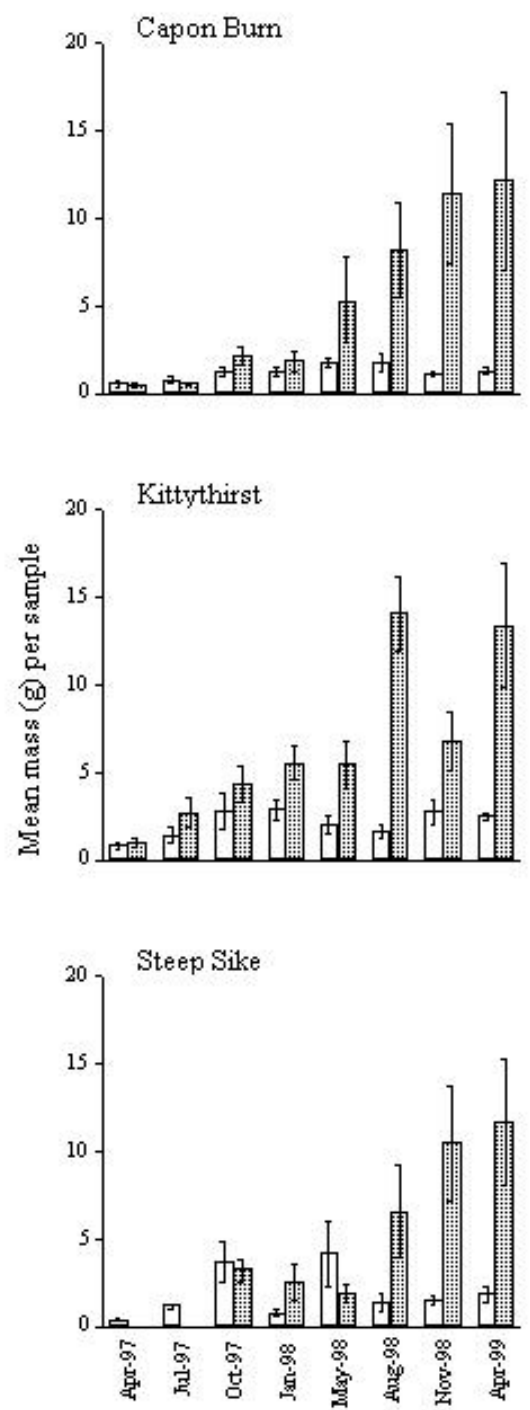

b) Woody detritus
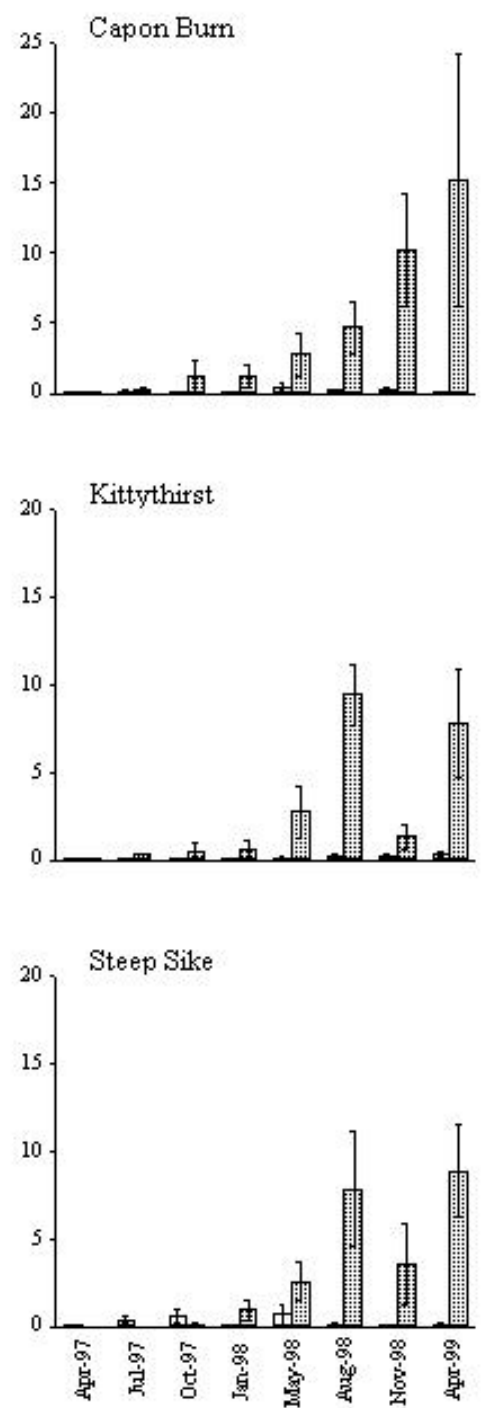

Fig. 1. Effect of manipulation on detrital standing stock. Clear bars = reference, shaded bars = manipulation. Premanipulation samples were taken in April 1997 for Capon Burn and Kittythirst and October 1997 for Steep Sike. Vertical axes show AFDM (g) per $0.0625 \mathrm{~m}^{2} \pm 1 S E$.

\section{Invertebrate abundance}

Overall, total invertebrate abundance and taxon richness were significantly higher in the manipulation samples relative to the references (Fig. 2; Table 4). This was true for each stream, although total invertebrate abundance at Kittythirst was a borderline exception with a $P$-value of exactly 0.05 .

The most common families at each site were generally more abundant in experimental reaches than references, although chironomid numbers were higher only at Kittythirst (Table 4). Among dominant mayfly families, Baetidae at Capon Burn, Heptageniidae at Kittythirst and Leptophlebiidae at Steep Sike did not differ in abundance between reference and experimental samples. At Kittythirst, however, baetid mayflies and elmid beetles maintained the higher densities in the reference reach that had been recorded from the pre-manipulation samples. The effect of sampling date on invertebrate abundance was highly significant for most of the common taxa at each site (Table 4), probably a reflection of the seasonal patterns of adult emergence and larval recruitment associated with most aquatic insect species. Unlike mass of detritus (Table 3), however, few invertebrate taxa showed a significant date/treatment interaction (Table 4).

\section{Discussion}

All three streams studied in Kielder Forest had low detrital 
Table 3. Two-way ANOVA comparing the effect of sampling date and treatment (reference vs. manipulation samples) on the mass of detritus $\left(\mathrm{g} 0.0625 \mathrm{~m}^{-2}\right)$ at each stream. Table shows F-values and associated probabilities.

\begin{tabular}{|c|c|c|c|c|c|c|}
\hline & \multicolumn{2}{|c|}{ Effect of treatment } & \multicolumn{2}{|c|}{ Effect ofdate } & \multicolumn{2}{|c|}{ Effect of interaction } \\
\hline & $F$ & $P$ & $F$ & $P$ & $F$ & $P$ \\
\hline CAPON BURN & \multicolumn{2}{|c|}{$(\mathrm{df}=1,56)$} & \multicolumn{2}{|c|}{$(\mathrm{df}=6,56)$} & \multicolumn{2}{|c|}{$(\mathrm{df}=6,56)$} \\
\hline Non-woody detritus & 53.46 & $<0.001$ & 3.93 & 0.002 & 3.03 & 0.012 \\
\hline Woody detritus & 52.89 & $<0.001$ & 8.91 & $<0.001$ & 6.39 & $<0.001$ \\
\hline KitTYTHIRST & \multicolumn{2}{|c|}{$(\mathrm{df}=1,56)$} & \multicolumn{2}{|c|}{$(\mathrm{df}=6,56)$} & \multicolumn{2}{|c|}{$(\mathrm{df}=6,56)$} \\
\hline Non-woody detritus & 28.79 & $<0.001$ & 5.22 & $<0.001$ & 3.07 & 0.011 \\
\hline Woody detritus & 33.77 & $<0.001$ & 3.06 & 0.012 & 2.65 & 0.025 \\
\hline Steep SiKe & \multicolumn{2}{|c|}{$(\mathrm{df}=1,40)$} & \multicolumn{2}{|c|}{$(\mathrm{df}=4,40)$} & \multicolumn{2}{|c|}{$(\mathrm{df}=4,40)$} \\
\hline Non-woody detritus & 22.20 & $<0.001$ & 3.33 & 0.019 & 4.39 & 0.005 \\
\hline Woody detritus & 36.64 & $<0.001$ & 2.34 & 0.072 & 2.32 & 0.073 \\
\hline
\end{tabular}

a) Total Abundance

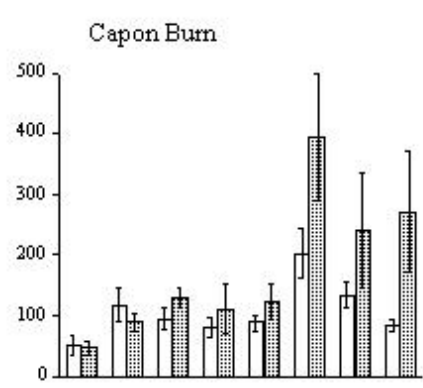

Kittythirst

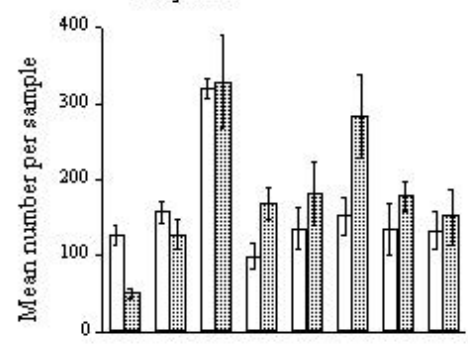

Steep Sike

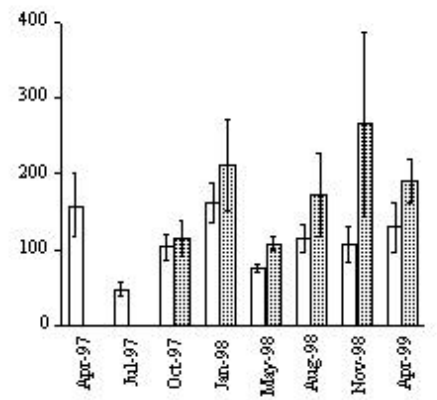

b) Taxon Richness

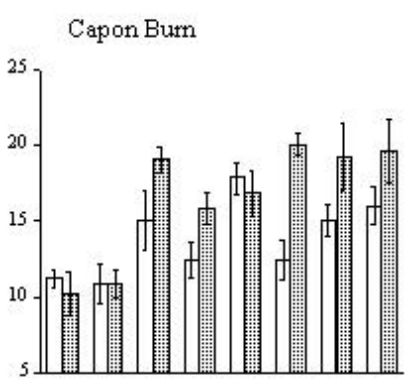

Kittythirst

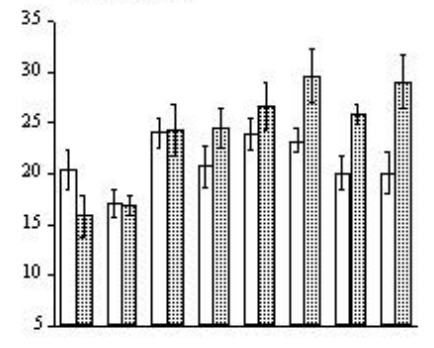

Steep Sike

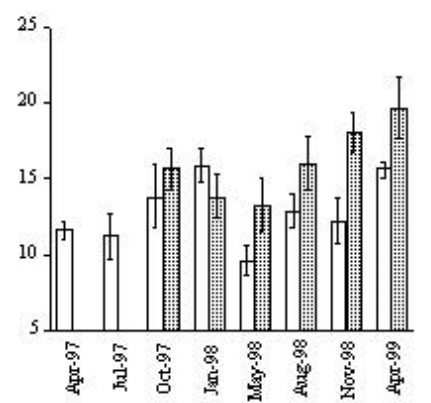

Fig. 2. Effect of manipulation on invertebrate abundance and taxon richness. Clear bars $=$ reference, shaded bars $=$ manipulation . Premanipulation samples were taken during April 1997 from Capon Burn and Kittythirst and October 1997 from Steep Sike. Vertical axes show numbers per $0.0625 \mathrm{~m}^{2} \pm 1$ SE. Note different scales on vertical axes. 
James L. Pretty and Michael Dobson

Table 4. Two-way ANOVA comparing the effect sampling date and treatment (reference vs. manipulation samples) on the invertebrate abundance and taxon richness at each stream. Table shows F-values and associated probabilities.

\begin{tabular}{|c|c|c|c|c|c|c|}
\hline & \multicolumn{2}{|c|}{ Effect of treatment } & \multicolumn{2}{|c|}{ Effect of date } & \multicolumn{2}{|c|}{ Effect of interaction } \\
\hline & $F$ & $P$ & $F$ & $P$ & $F$ & $P$ \\
\hline CAPON BuRn & \multicolumn{2}{|c|}{$(\mathrm{df}=1,56)$} & \multicolumn{2}{|c|}{$(\mathrm{df}=6,56)$} & \multicolumn{2}{|c|}{$(\mathrm{df}=6,56)$} \\
\hline Total invertebrates & 5.36 & 0.024 & 4.38 & 0.001 & 0.86 & 0.530 \\
\hline Taxon richness & 15.36 & $<0.001$ & 6.94 & $<0.001$ & 1.86 & 0.104 \\
\hline Chironomidae & 1.12 & 0.230 & 2.67 & 0.024 & 0.97 & 0.455 \\
\hline Nemouridae & 13.13 & 0.001 & 25.58 & $<0.001$ & 1.56 & 0.175 \\
\hline Leuctridae & 4.93 & 0.030 & 6.46 & $<0.001$ & 2.27 & 0.050 \\
\hline Baetidae & 4.98 & 0.487 & 42.75 & $<0.001$ & 0.62 & 0.716 \\
\hline Simuliidae & 10.94 & 0.002 & 60.22 & $<0.001$ & 1.55 & 0.180 \\
\hline Taeniopterygidae & 0.44 & 0.508 & 43.79 & $<0.001$ & 0.73 & 0.631 \\
\hline Polycentropodidae & 0.04 & 0.847 & 8.19 & $<0.001$ & 0.32 & 0.927 \\
\hline KITTYTHIRST & \multicolumn{2}{|c|}{$(\mathrm{df}=1,56)$} & \multicolumn{2}{|c|}{$(\mathrm{df}=6,56)$} & \multicolumn{2}{|c|}{$(\mathrm{df}=6,56)$} \\
\hline Total invertebrates & 4.02 & 0.050 & 5.62 & $<0.001$ & 1.25 & 0.294 \\
\hline Taxon richness & 13.76 & $<0.001$ & 6.00 & $<0.001$ & 1.48 & 0.201 \\
\hline Baetidae & 7.44 & 0.009 & 7.36 & $<0.001$ & 1.19 & 0.324 \\
\hline Gammaridae & 8.70 & 0.005 & 5.16 & $<0.001$ & 1.05 & 0.406 \\
\hline Heptageniidae & 1.77 & 0.189 & 52.03 & $<0.001$ & 2.50 & 0.032 \\
\hline Leuctridae & 14.14 & $<0.001$ & 5.98 & $<0.001$ & 1.94 & 0.090 \\
\hline Elmidae & 9.77 & 0.003 & 2.26 & 0.050 & 1.56 & 0.176 \\
\hline Chironomidae & 66.40 & $<0.001$ & 29.62 & $<0.001$ & 3.04 & 0.012 \\
\hline Nemouridae & 9.85 & 0.003 & 9.35 & $<0.001$ & 1.31 & 0.270 \\
\hline Simuliidae & 12.94 & $<0.001$ & 3.54 & 0.005 & 0.23 & 0.965 \\
\hline Tipulidae & 0.03 & 0.955 & 3.30 & 0.008 & 1.40 & 0.232 \\
\hline Steep Sike & \multicolumn{2}{|c|}{$(\mathrm{df}=1,40)$} & \multicolumn{2}{|c|}{$(\mathrm{df}=4,40)$} & \multicolumn{2}{|c|}{$(\mathrm{df}=4,40)$} \\
\hline Total invertebrates & 5.99 & 0.019 & 1.76 & 0.156 & 0.49 & 0.746 \\
\hline Taxon richness & 10.04 & 0.003 & 5.45 & 0.001 & 2.29 & 0.076 \\
\hline Nemouridae & 18.99 & $<0.001$ & 29.57 & $<0.001$ & 1.99 & 0.115 \\
\hline Leuctridae & 7.21 & 0.011 & 5.15 & 0.002 & 0.16 & 0.957 \\
\hline Chironomidae & 2.37 & 0.132 & 57.78 & $<0.001$ & 0.17 & 0.953 \\
\hline Simuliidae & 4.45 & 0.041 & 8.46 & $<0.001$ & 0.19 & 0.945 \\
\hline Taeniopterygidae & 0.24 & 0.628 & 31.52 & $<0.001$ & 0.31 & 0.870 \\
\hline Polycentropodidae & 0.02 & 0.966 & 5.77 & $<0.001$ & 0.06 & 0.993 \\
\hline Leptophlebiidae & 0.01 & 0.949 & 13.01 & $<0.001$ & 1.09 & 0.373 \\
\hline
\end{tabular}

standing stocks in their reference reaches, more characteristic of open moorland streams (e.g. Dobson et al., 1995; Cariss and Dobson, 1997) than forest streams. Values recorded from wooded streams are generally in excess of $100 \mathrm{gm}^{-2}$ (e.g. Wallace et al., 1995b; Marxsen et al., 1997; Smock, 1997) compared with an average from Kielder Streams of $32 \mathrm{gm}^{-2}$. Interestingly, the difference in background detrital standing stocks between Kielder and other wooded streams was not simply an effect of conifer trees, as evidenced by the equally low retention in Steep Sike where the riparian zone was dominated by alder trees. Addition of logs successfully enhanced detritus retention on the streambed in all three manipulated streams. Increases were most apparent in the second half of the study period; indeed, analysis of the first year alone revealed little increase (Pretty and Dobson, 2001). The slow initial response was probably due to the nature of the DW added. For the purpose of easy replication, the logs used were of a uniform shape and size with all side branches removed. It was expected that they would quickly accumulate small sticks and branches that would further enhance retention. However, the smooth, round shape of the logs meant they were slow to catch DW and the main retention feature was the steel poles that held the logs in place. Despite the slow response, 
the wood-pole manipulation became more effective over time with the amount of detritus retained being greater in the second year of the study (Fig. 1). More complex structures, like natural woody inputs with side branches, would presumably retain detritus more rapidly.

Despite the low natural levels of detritus, the invertebrate fauna in the Kielder streams was dominated by detritivores. This raises questions about their dependence upon a detrital food source, and it is becoming increasingly well documented that many stream invertebrates are opportunistic feeders. For instance, feeding plasticity has been demonstrated for detritus-feeders such as amphipods and trichopterans (e.g. Winterbourn et al., 1985; Friberg and Jacobsen, 1994; Mihuc and Mihuc, 1995). Similarly, Ledger and Hildrew (2000) found that nemourid stoneflies could effectively graze epilithic biofilm as an alternative to allochthonous detritus. It is likely, therefore, that feeding plasticity may have assisted the large detritivore populations present in the Kielder streams. Regardless, invertebrate assemblages clearly benefited (in terms of numbers and species richness) from the increased availability of detritus, and the positive response was strongest among groups typically regarded as detritivores (e.g. Nemouridae and Leuctridae). Despite this response, there was no evidence for an increase in invertebrate abundance over time as the retention structures became more efficient. Therefore, the log-pole addition may have increased numbers of invertebrates not simply by enhancing a specific resource but by a general manipulation of the streambed habitat. Logs acted as stabilising influences on the channel, and their influence on physical and hydraulic characteristics may have been their most important effect. For example, similar logaddition experiments altered local current velocities, redistributed channel substrata and promoted the formation of pools (Hilderbrand et al., 1997; Wallace et al., 1995a; Lehane et al., 2002). Such changes to stream morphology may contribute to habitat heterogeneity/complexity and influence invertebrate community structure and secondary production (Wallace et al., 1995a; Lemly and Hilderbrand, 2000).

In this study, the addition of logs resulted in a general increase in invertebrate numbers and also in taxon richness. Furthermore, there was no evidence for the manipulation having a detrimental influence on any component of the fauna. Therefore, using several criteria, the manipulation appeared to enhance the invertebrate community of the study streams. The study may underestimate the full effect of logpole addition, as practical constraints meant that samples from the manipulated reach were taken immediately downstream of logs, whereas their greatest influence on detritus aggregation was probably immediately upstream
(Wallace et al., 1995a).

It is possible that enhanced numbers were an artefact created by the redistribution of invertebrates already present in the experimental reach, rather than a genuine increase in invertebrate populations. Such aggregations could occur through active foraging as well as by drifting invertebrates accumulating in 'dead zones' created by the manipulation (cf Lancaster and Hildrew, 1993; Lancaster, 1999). Whilst such small-scale movements undoubtedly occur (Winterbottom et al., 1997), invertebrates are quick to colonise free space and it is unlikely that areas between traps would remain depleted for long. There is also evidence that increasing detrital food sources could enhance overall invertebrate production (Richardson, 1991; Richardson and Neill, 1991; Basset and Glazier, 1995). If this were to benefit adult fecundity (larger females may carry more eggs) there is potential for enhanced recruitment in the next generation. A further potential role of the detritus accumulations is as oviposition sites. Circumstantial evidence from Capon Burn supported this idea; here detritus accumulations contained many young nemourid larvae relative to the natural substrate (J.L. Pretty, pers. obs.). However, further research would be necessary to demonstrate whether this association was due to oviposition or invertebrate drift.

\section{MANAGEMENT IMPLICATIONS}

Clearly this study was relatively short term and carried out over a small spatial scale. It does, however, contribute valuable information to the debate on management of streams running through commercial plantations. In the United Kingdom, the Forestry Commission has produced management guidelines that recommend leaving open or lightly-shaded buffer zones between the stream and the planted trees (Forestry Commission, 1993). These buffer zones are valuable in maintaining invertebrate diversity (e.g. Rundle et al., 1992; Ormerod et al., 1993) and are probably the most appropriate management strategy for such systems. While replacing such a management strategy in favour of heavily shaded streams is not advocated here, allowing streamside trees to mature may be the best option in some circumstances. Many riparian areas, planted before buffer zones were common practice, now support mature trees. The removal of trees simply to create an open buffer zone would involve major disturbance to the detriment of the stream fauna. Rather than create an open environment within the plantation, it may, therefore, be more viable to adopt a 'do nothing' approach and allow the riparian zone to mature, senesce and regenerate naturally (Dobson and Cariss, 1999). The creation of old growth forest (trees $>100$ years old) has been recognised as an important strategy to enhance the 
conservation value of plantation forests, for both aquatic and terrestrial species (Peterken, 1996). Furthermore, Peterken et al., (1992) suggest that old growth would ideally be situated on the lower slopes of valleys, where wind damage is reduced and soil and microclimate are more favourable. This strategy is not entirely compatible with current Forestry Commission guidelines, but patches of old growth forest along river margins could complement open buffer zones and maximise habitat heterogeneity within an area of commercial forestry.

By definition, old growth forest takes time to develop. However, its most important effect on streams - input of DW - can be simulated. Detritus manipulation studies using retention devices to enhance standing stocks have now been carried out in numerous streams covering a range of water chemistry features and riparian vegetation types (Dobson and Hildrew, 1992; Dobson et al., 1995; Murphy and Giller, 2000; Muotka and Laasonen, 2002; this study). In all of these studies, increased detrital standing stocks have been achieved easily and at least some components of the invertebrate fauna responded positively to the increase in detritus availability, suggesting that the method is fairly robust. In addition, activity of aquatic hyphomycete fungi increases when detritus levels are artificially enhanced (Laitung et al., 2002); this will increase rates of conditioning and improve the quality of the detritus retained as a food resource for detritivores. Therefore, if riparian areas of forestry are to be removed from the commercial sphere, their positive effects on streams can be accelerated by simple channel manipulation, like the type described here. This change will enhance stream productivity and, if the results from this study are generally applicable, increase species richness, particularly benefiting less common species. Furthermore, the manipulation requires little maintenance, making it a cost-effective form of management. In due course, as trees reach the old growth stage, inputs of wood will occur naturally, thus removing the requirement for further management.

\section{Acknowledgements}

Jonathan Humphrey (Forest Research) is thanked for his assistance in facilitating this project's realisation, and Forest Enterprise for access to field sites.

\section{References}

Bärlocher, F., Kendrick, B. and Michaelides, J., 1978. Colonisation and conditioning of Pinus resinosa needles by aquatic hyphomycetes. Arch. Hydrobiol., 81, 462-474.

Basset, A. and Glazier, D.S., 1995. Resource limitation and intraspecific patterns of weight-length variation among spring detritivores. Hydrobiologia, 316, 127-137.
Behmer, D.J. and Hawkins, C.P., 1986. Effects of overhead canopy on macroinvertebrate production in a Utah stream. Freshwater Biol., 16, 287-300.

Campbell, I.C., James, K.R., Hart, B.T. and Deveraux, A., 1992. Allochthonous coarse particulate organic material in forest and pasture reaches of two south-eastern Australian streams. I. Litter accession, Freshwater Biol., 27, 341-352.

Cariss, H. and Dobson, M., 1997. Transport and retention of detritus in upland streams: a comparison of an open stream and an adjacent wooded site. Limnética, 13, 85-91.

Dobson, M. and Cariss, H., 1999. Restoration of afforested upland streams - what are we trying to achieve? Aquat. Conserv: Mar. Freshwater Ecosyst., 9, 133-139.

Dobson, M. and Hildrew, A.G., 1992. A test of resource limitation among shredding detritivores in low order streams in southern England. J. Anim. Ecol., 61, 69-78.

Dobson, M., Hildrew, A.G., Orton, S. and Ormerod, S.J., 1995. Increasing litter retention in moorland streams: ecological and management aspects of a field experiment. Freshwater Biol., 33, 325-337.

Forestry Commission, 1993. Forests and Water Guidelines. HMSO, London, UK.

Friberg, N., 1997. Benthic invertebrate communities in six Danish forest streams: impact of forest type on structure and function. Ecography, 20, 19-28.

Friberg, N. and Jacobsen, D., 1994. Feeding plasticity of two detritivore-shredders. Freshwater Biol., 32, 133-142.

Friberg, N. and Kjeldsen, K., 1994. Development of benthic algal biomass in six Danish beech, mixed and coniferous forests. Verh. Internat. Verein. Limnol., 25, 1534-1538.

Friberg, N., Larsen, A.D., Rodkjaer, A. and Thomsen, A.G., 2002. Shredder guilds in three Danish forest streams contrasting in forest type. Arch. Hydrobiol., 153, 197-215.

Graça, M.A.S. and Pereira, A.P., 1995. The degradation of pine needles in a Mediterranean stream. Arch. Hydrobiol., 134, 119128.

Grafius, E. and Anderson, N.H., 1980. Population dynamics and role of two species of Lepidostoma (Trichoptera: Lepidostomatidae) in an Oregon coniferous forest stream. Ecology, 61, 808-816.

Haapala, A. and Muotka, T., 1998. Seasonal dynamics of detritus and associated macroinvertebrates in a channelised boreal stream. Arch. Hydrobiol., 142, 171-189.

Hibberd, B.G., 1985. Restructuring of plantations in Kielder Forest District. Forestry, 58, 119-129.

Hilderbrand, R.H., Lemly, A.D., Dolloff, C.G. and Harpster, K.L., 1997. Effects of large woody debris placement on stream channels and benthic macroinvertebrates. Can. J. Fisheries Aquat. Sci., 54, 931-939.

Hornung, M. and Newson, M.D., 1986. Upland afforestation: influences on stream hydrology and chemistry. Soil Use Manage., 2, 61-65.

Laitung, B., Pretty, J.L., Chauvet, E. and Dobson, M., 2002. Response of aquatic hyphomycete communities to enhanced stream retention in areas impacted by commercial forestry. Freshwater Biol., 47, 313-323.

Lancaster, J., 1999. Small-scale movements of lotic macroinvertebrates with variations in flow. Freshwater Biol., 41, 605-619.

Lancaster, J. and Hildrew, A.G., 1993. Flow refugia and the microdistribution of lotic macroinvertebrates. J. N. Amer. Benthol. Soc., 12, 385-393.

Ledger, M.E. and Hildrew, A.G., 2000. Herbivory in an acid stream. Freshwater Biol., 43, 545-556. 
Leeks, G.J.L. and Roberts, G., 1987. The effects of forestry on upland streams - with special reference to water quality and sediment transport. In: Environmental Aspects of Plantation Forestry in Wales, J.E. Good (Ed.), Institute of Terrestrial Ecology, Grange-Over-Sands, UK. 9-24.

Lehane, B.M., Giller, P.S., O'Halloran, J., Smith, C. and Murphy, J., 2002. Experimental provision of large woody debris in streams as a trout management technique. Aquat. Conserv. Mar. Freshwat. Ecosyst., 12, 289-311.

Lemly, A.D. and Hilderbrand, R.H., 2000. Influence of large woody debris on stream insect communities and benthic detritus. Hydrobiologia, 421, 179-185.

Marxsen, J., Schmidt, H. and Fiebig, D.M., 1997. Organic matter dynamics in the Breitenbach, Germany. J. N. Amer. Benthol. Soc., 16, 28-32.

Mihuc, T.B. and Mihuc, J.R., 1995. Trophic ecology of five shredders in a Rocky Mountain stream. J. Freshwater Ecol., 10, 209-216.

Muotka, T. and Laasonen, P., 2002. Ecosystem recovery in restored headwater streams: the role of enhanced leaf retention. J. Appl. Ecol., 39, 145-156.

Murphy, J.F. and Giller, P.S., 2000. Seasonal dynamics of macroinvertebrate assemblages in the benthos and associated with detritus packs in two low-order streams with different riparian vegetation. Freshwater Biol., 43, 617-631.

O'Halloran, J. and Giller, P.S., 1993. Forestry and the ecology of streams and rivers: lessons from abroad. Irish Forestry, 50, 35-52.

Ormerod, S.J., Mawle, G.W. and Edwards, R.W., 1987. The influence of forest on aquatic fauna. In: Environmental Aspects of Plantation Forestry in Wales, J.E. Good (Ed.), Institute of Terrestrial Ecology, Grange-Over-Sands, UK. 37-49.

Ormerod, S.J., Rundle, S.D., Lloyd, E.C. and Douglas, A.A., 1993. The influence of riparian management on the habitat structure and macroinvertebrate communities of upland streams draining plantation forests. J. Appl. Ecol., 30, 13-24.

Peterken, G.F., 1996. Natural Woodland. Ecology and Conservation in Northern Temperate Regions. Cambridge University Press, Cambridge, UK.

Peterken, G.F., Ausherman, D., Buchenau, M. and Forman, R.T.T., 1992. Old-growth conservation within British upland conifer plantations. Forestry, 65, 127-144.
Pozo, J., Basaguren, A., Elosegui, A., Molinero, J., Fabre, E. and Chauvet, E., 1998. Afforestation with Eucalyptus globulus and leaf litter decomposition in streams of northern Spain. Hydrobiologia, 373, 101-109.

Pretty, J.L. and Dobson, M., 2001. A possible strategy for enhancing the stream biota in areas of intensive commercial forestry. Verh. Internat. Verein. Limnol., 27, 1075-1078.

Richardson, J.S., 1991. Seasonal food limitation of detritivores in a montane stream: an experimental test. Ecology, 72, 873-887.

Richardson, J.S. and Neill, W.E., 1991. Indirect effects of detritus manipulations in a montane stream. Can. J. Fisheries Aquat. Sci., 48, 776-783.

Rundle, S.D., Lloyd, E.C. and Ormerod, S.J., 1992. The effects of riparian management and physicochemistry on macroinvertebrate feeding guilds and community structure in upland British streams. Aquat. Conserv: Mar. Freshwat. Ecosyst., 2, 309-324.

Smock, L.A., 1997. Organic matter dynamics in Buzzards Branch, a blackwater stream in Virginia, USA. J. N. Amer. Benthol. Soc., 16, 54-57.

Tierney, D., Kelly-Quinn, M. and Bracken, J.J., 1998. The faunal communities of upland streams in the eastern region of Ireland with reference to afforestation impacts. Hydrobiologia, 389, $115-130$.

Wallace, J.B., Webster, J.R. and Meyer, J.L., 1995a. Influence of $\log$ additions on physicaland biotic characteristics of a mountain stream. Can. J. Fisheries Aquat. Sci., 52, 2120-2137.

Wallace, J.B., Whiles, M.R., Eggert, S., Cuffney, T.F., Lugthart, G.J. and Chung, K., 1995b. Long term dynamics of coarse particulate organic matter in three Appalachian mountain streams. J. N. Amer. Benthol. Soc., 14, 217-232.

Weatherley, N.S. and Ormerod, S.J., 1990. Forests and the temperature of upland streams in Wales: a modelling exploration of the biological effects. Freshwater Biol., 24, 109-122.

Winterbottom, J.H., Orton, S.E. and Hildrew, A.G., 1997. Field experiments on the mobility of benthic invertebrates in a southern English stream. Freshwater Biol., 38, 37-47.

Winterbourn, M.J., Hildrew, A.G. and Box, A., 1985. Structure and grazing of stone surface organic layers in some acid streams of Southern England. Freshwater Biol., 15, 363-374. 